\title{
PERFORMANCE OF SEVENTEEN POPLAR CLONES IN SOUTH CENTRAL SASKATCHEWAN ${ }^{1}$
}

\author{
By W. H. CRAM ${ }^{2}$
}

William Hugh Cram graduated from the University of Manitoba with a B.S.A. (1939) in Plant Science, an M. Sc. (1948) in Plant Breeding, and from the University of Minnesota a Ph. D. (1951) in Genetics. He was a Field Supervisor for the Forest Nursery Station (1941-42), was overseas with the R.C.A.F. (1942-45), was a Plant Breeder (1947-58) and since 1958 has been Superintendent at the Forest Nursery Station, Indian Head, Sask.

\section{ABSTRACT}

Survival of seventeen poplar clones six years after planting in 1951 ranged from 0 to 100 per cent. Total height of the surviving 13 clones in. 1956 varied from 11 to 25 feet. FNS No. 44-52, a natural hybrid of $P$. deltoides, was the outstanding clone in the test with a survival of 94 per cent and height of 25 feet. Three clones, FNS No. 44-52, Saskatchewan, and BNW No. 4 demonstrated resistance to disease (Cytospora canker), while ten clones proved highly susceptible. Survival and growth for FNS No. 44-52, 38P38, tristis No. 1 and gelrica were superior to those of Northwest poplar, which exhibited a survival of 75 per cent and height of 18 feet.

\section{INTRODUCTION}

Poplars are planted in prairie shelterbelts primarily to provide early shelter with their rapid growth. One requisite of poplar clones distributed for shelterbelt plantings is the ability to root readily from cuttings. This characteristic is essential for mass production and economical shipment of such plant material. Other requirements of poplars for the prairies are winter-hardiness, drought tolerance, and resistance to prevailing diseases. Few poplars now persist in shelterbelts due to the adverse effects of drought, insects and diseases. These losses demonstrate a need for research to select the most promising species and clones for future prairie planting and for improvement by breeding.

Little information has been published on the performance of poplar clones in the prairie region of North America. Meagre records on the growth and survival of poplar are available from shelterbelt tests that were conducted in the Great Plains area of the United States from 1915 to 1943. Unfortunately these tests were limited to mixed plantings of only one or two poplar clones or species with several other kinds of trees. In two of these tests the poplar plantings were reported $(6,9)$ as being destroyed by Cytospora canker.

In more recent years, the selection and testing of native poplars, and of natural and artificial hybrids, has greatly increased. This work was stimulated by Stout and Schreiner (13) in the United States, and by Heimburger (5) in Canada. Some of the new introductions have demonstrated resistance to diseases, as well as outstanding vigor with improved rooting and hardiness.

\footnotetext{
${ }^{1}$ Contribution No. 7. Forest Nursery Station, Indian Head.

${ }^{9}$ Superintendent, Forest Nursery Station, Canada Department of Agriculture, Indian Head, Saskatchewan.
} 
Clones of the new poplar species and hybrids have been in test plantings at the Forest Nursery Station, Indian Head, Saskatchewan, since 1942. The present paper reports the results up to 1956 of a 1951 test planting involving 17 of the most promising (1) of these clones.

The Forest Nursery Station at Indian Head at $50^{\circ} 31 \mathrm{~N}, 103^{\circ} 41^{\prime} \mathrm{W}$, altitude 1936 feet, is located in the central part of Southern Saskatchewan. Weather records at the station for the 1951-56 period show the frost-free period varied from 113 to 127 days, whereas the growing season with temperatures above $40^{\circ} \mathrm{F}$ ranged from 105 to 121 days. The average precipitation in the growing season at Indian Head for this period was 13.5 inches.

\section{Materials and Methods}

Prior to 1947, more than 80 hybrids and 40 species of poplar had been established in test plantings on the Forest Nursery Station at Indian Head. Investigations on the rooting ability of these poplar clones were conducted from 1948 to 1951 (1). Rooting ability is the stand of established plants in the fall expressed as a percentage of the cuttings planted in the spring. The current study is restricted to seventeen clones, which had previously demonstrated most promise under prairie conditions and had exhibited good rooting ability.

Table 1 lists the seventeen clones with all available information on the parentage and origin of each. Each clone is listed as a species (S), or as an artificial (A) or natural (N) hybrid, and its known parentage and originator or source are given. In all cases the names of clones are those under which they were received. The author is indebted to Dr. C. Heimburger, of the Southern Research Station, Department of Lands and Forests, Maple, Ontario, for information as to the parentage and source for most of the hybrid clones listed.

TABLE 1

Parentage and Source of Poplar Clones in Study

\begin{tabular}{|c|c|c|c|}
\hline $\begin{array}{l}\text { Clone } \\
\text { Name }\end{array}$ & $\begin{array}{l}\text { Type or } \\
\text { Origin }\end{array}$ & Parentage & $\begin{array}{l}\text { Originator } \\
\text { or Source }\end{array}$ \\
\hline P. angustifolia & S. & Native Narrowleaf Cottonwood & Cent. Plains \\
\hline P. $X A S \# 2$ & A. & $P$. angulata $x P$. Simonii & C. Heimburger \\
\hline P. $X B N W \# 4$ & A. & P. berolinensis $\times$. Northwest & C. Heimburger \\
\hline P. $X 38 P 38$ & A. & P. tacamahaca $x$ Simonii & E. C. Smith \\
\hline P. Brooks \#4 & $\mathrm{N}$. & P. deltoides $\mathrm{x}$ Russian? & E. Griffin \\
\hline P. Brooks \#7 & N. & P. deltoides $\mathrm{x}$ Russian? & E. Griffin \\
\hline P. Brooks \#10 & N. & P. deltoides $\mathrm{x}$ Russian? & E. Griffin \\
\hline P. Dunlop & N. & ? male of Russian type & R. H. Dunlop (FNS) \\
\hline P. FNS \#44-52 & N. & P. deltoides $\mathrm{x}$ ? & J. Walker (FNS) \\
\hline P. gelrica & N. & $P$. canadensis $\times$ P. nigra & G. Houtzagers \\
\hline$P$. incrassata & N. & P. nigra hybrid & Dow Chem. Co. \\
\hline P. Northwest & N. & P. deltoides $\mathrm{x}$ balsam? & Prairie Nurseries \\
\hline P. Saskatchewan & $N$. & P. deltoides $\mathrm{x}$ ? & F.N.S. Indian Head \\
\hline P. Sargentii & S. & Native Western Cottonwood & Cent. Plains \\
\hline P. tristis \#1 & A. & $P$. balsamifera $\times P$. tristis & F. L. Skinner \\
\hline P. Volunteer & N. & ? female of Russian type & W. L. Kerr (FNS) \\
\hline P. Wheeler \#4 & $\mathrm{N}$. & P. deltoides $\mathrm{x}$ ? & S. Wheeler \\
\hline
\end{tabular}


The terminal shoots of sexually mature plants of 17 clones were harvested on October 25, 1950. Each shoot was cut into lengths of ten inches. All cuttings were classified into basal diameter groups. Only those with diameters from 6 to 10 millimeters were retained for the study. Twelve cuttings, six each of the 6 to 8 and 8 to 10 millimeter size, were tied in bundles and heeled-in outdoors on October 30. They were removed on May 8, 1951, and planted. A randomized block design with eight replications was utilized for the planting. Cuttings were planted four inches apart in the row, in rows four feet apart, and twelve cuttings per plot. Two additional clones, which were highly susceptible to rust and canker diseases, were planted in two border rows for the test. The planting site was a cleared area adjacent to a natural stand of Aspen poplar (Populus tremuloides Michx.) on the station.

Stand and growth records were taken on October 1, 1951. At this time the stand was thinned to approximately four feet apart in the rows to provide single plant plots, at $4 \times 4$ foot spacing, for the subsequent performance test. The plantation was maintained under clean cultivation from 1951 to 1954, after which only a twenty-foot border around the planting was cultivated. On August 30, 1956, records on survival, disease and height were taken. The number and severity of cankers were tabulated for all surviving plants, and a disease rating of 0 to 5 was assigned to each. Total height of each plant was recorded as a measure of vigor.

\section{RESULTS}

Table 2 presents a summary of the rooting ability, the survival and height to 1956 , as well as the disease incidence, for the 17 clones. It is apparent from this summary that clones differ greatly in these characteristics.

Rooting ability of the seventeen clones appeared to fall into five general groups and on the average was 70 per cent. Outstanding rooting (in excess of 90 per cent) was demonstrated by two clones, namely Dunlop and volunteer. Rooting ability exceeding 75 per cent was evident for four clones, tristis No. 1 , FNS No. 44-52, Brooks No. 10, and Wheeler No. 4. Moderate rooting, from 74 to 67 per cent, was exhibited by the six clones, Brooks No. 7, Saskatchewan, gelrica, AS No. 2, 38P38, and Brooks No. 4. Low to poor rooting ranging from 61 to 45 per cent was recorded for the remaining clones, which included the standard Northwest poplar.

A negative relationship between survival and incidence of disease was apparent from the data listed in Table 2. Survival and stand in 1956, when expressed as a percentage of the plants established in 1951, varied from 0 to 100 per cent for the seventeen clones. Stands of 94 to 100 per cent were manifested by the three clones for which few to no disease cankers were recorded. Survivals of 6 to 25 per cent for five clones were associated with the highest incidences of disease. Between these two extremes were four clones with survivals of 75 to 87 per cent and low incidences of disease. In addition four clones were completely eliminated, most likely due to disease, prior to 1956 .

The three clones with outstanding survival and resistance to disease, were BNW No. 4, FNS No. 44-52 and Saskatchewan. Four clones with moderate survival and some disease tolerance were $38 \mathrm{P} 38$, tristis No. 1 , gelrica, and Northwest. The remaining ten clones were evidently highly susceptible to disease and of little value for shelterbelts in the Indian Head area. 
TABLE 2

Rooting Ability in 1951 and Subsequent Survival, Disease, and Height IN 1956 for Seventeen Clones of Poplar

\begin{tabular}{|c|c|c|c|c|}
\hline Clone & Rooting ${ }^{1}$ & Survival $^{2}$ & Disease $^{3}$ & Height \\
\hline & (per cent) & (per cent) & (rating) & (ft.) \\
\hline P. FNS \#44-52 & 78 & 94 & 0 & 25.0 \\
\hline P. $38 P 38$ & 67 & 75 & 2 & 20.6 \\
\hline$P$. tristis $\# I$ & 84 & 87 & 2 & 20.0 \\
\hline P. gelrica & 73 & 87 & 2 & 18.5 \\
\hline P. Northwest & 59 & 75 & 1 & 17.8 \\
\hline P. Brooks \#4 & 67 & 6 & 1 & 15.9 \\
\hline P. Sargentii & 55 & 19 & $4^{*}$ & 15.6 \\
\hline P. Brooks \#7 & 74 & 25 & 4 & 15.3 \\
\hline P. incrassato & 45 & 6 & $3^{*}$ & 13.6 \\
\hline P. Dunlop & 92 & 19 & 3 & 12.9 \\
\hline P. Saskatchewan & 74 & 94 & 1 & 12.9 \\
\hline P. $B N W \# 4$ & 61 & 100 & 0 & 12.2 \\
\hline P. Wheeler $\# 4$ & 76 & 6 & 5 & 11.1 \\
\hline P. volunteer & 91 & 0 & - & - \\
\hline P. Brooks \#10 & 77 & 0 & - & - \\
\hline P. $A S \# 2$ & 68 & 0 & - & - \\
\hline P. angustifolia & 59 & 0 & - & - \\
\hline
\end{tabular}

${ }^{1}$ Established plants in the fall of 1951 as a percentage of the cuttings planted.

"Survival in 1956 as a percentage of the plants established in 1951.

"Rating from 0 to 5 for incidence of cankers ("die-back).

- Average height in feet of plants surviving in 1956.

Total height of the 6-year-old plants varied from 11 to 25 feet for the 13 surviving clones. An outstanding rate of growth, which averaged four feet each year, was demonstrated by one clone, FNS No. 44-52. Growth averaged three feet a year for $38 \mathrm{P} 38$, tristis No. 1, gelrica, and Northwest. Fair to poor growth of two to two and a half feet a year was recorded for the remaining clones including Saskatchewan and BNW No. 4.

\section{Discussions AND CONCLUSIONS}

The present study has demonstrated the merit of selecting the proper clone, when planting poplar in the Canadian prairies. Survival and growth data for Northwest poplar and other clones in this study compare favorably with corresponding data for similar plantings in other areas of North America. George (3) reported a survival of 88 per cent and height of 12 feet for Northwest poplar in North Dakota under a seasonal precipitation of 11 inches for six years. Jensen and Harrington (6) reported a survival of two per cent and height of 13 feet for 11-year-old plantings of Northwest poplar in Montana under a season precipitation of 8.6 inches. At Indian Head the survival of Northwest poplar was 75 per cent and the height in six years was 17 feet, under a seasonal precipitation of 13.5 inches. In North Carolina (2) the survival of 12 poplar hybrids varied from 7 to 76 per cent and height from 25 to 54 feet after 19 years. In Michigan (4) survival of 8 hybrids was 60 per 
cent with an average height of 19 feet six years after planting. Johnson (7) reported an average height of 17.6 feet for a 5-year-old hybrid. Populus Sargentii attained a height of 10 feet with 59 per cent survival in six years under shelter-belt conditions (9). One clone in the present study, FNS No. 44-52, with a survival of 94 per cent and height of 25 feet in six years, was superior to the clones cited in the above reports. The rate of growth exhibited by five clones in Table 2 shows the potential of poplars in this area, despite such climatic limitations as drought and winter injury.

The relationship found between the incidence of disease and survival for this study suggests that disease is a major problem of poplars in the prairie region. This problem has been previously reported from studies in the Great Plains (9), in Montana (6), Wisconsin (7), South Dakota (10), and Canada $(11,12)$. It was supported by isolations (14) of Septoria: sp. and Cytospora sp. from disease cankers in the present study.

The following conclusions and recommendations may be drawn from the present study: 1 . Seven of the 17 clones in this study are recommended for planting in areas which are comparable to the Indian Head district. The clones are as follows in order of preference: FNS No. 44-52, 38P38, tristis No. 1, gelrica, BNW No. 4, Northwest, and Saskatchewan. Use of these clones should produce stands of 75 to 100 per cent with average heights of 12 to 25 feet in six years. As FNS No. 44-52 is a female clone, plantings of it should be limited to locations where regeneration would not create a problem. 2 . Three clones were indicated as potential breeding stocks for the improvement of poplars by the present study. These are FNS No. 44-52, Saskatchewan, and BNW No. 4, all of which demonstrated a high degree of resistance to the prevailing diseases. 3. Similar test plantings of poplar clones should be establshed in the various climatic and soil zones of the Canadian prairies. Results from such tests provide the only means of ensuring permanent and satisfactory shelterbelts in the future.

\section{References Cited}

1. CRAM, W. H. and G. A. MORGAN, 1960. Rooting of Poplar Clones in Prairie Canada, Tree Planters Notes (In press).

2. DOOLITTLE, W. T. 1953. Growth and Survival of Hybrid Poplars, Sth. Lumberm. 187: $178-179$.

3. GEORGE, E. J. 1936. Growth and survival of deciduous trees in shelter-belt experiments at Manden, N. Dak., 1915-34. U.S.D.A. Tech. Bull. No. 496.

4. GYSEL, L. W. 1949. The survival and growth of hybrid poplars in four Michigan test areas. Quart. Bull. Mich. Agri. Exp. Sta. 32: 156-165.

5. HEIMBURGER, C. 1940. Report on poplar lyybridization II, 1937 and 1938. For. Chma. 16: $149-160$.

6. JENSEN, I. J. and F. M. HARRINGTON, 1930. Dry-land shelter-belt rests at the Judith Basis Branch Station. Univ. Montana Agri. Exp. Sta. Bull. No. 233.

7. JOHNSON, L. P. V. 1946. A note on inheritance in $F_{1}$ and $F_{2}$ hybrids of Populus aiba, L. $x$ P. grandidentata Michx. Can. J. Res. (C) 24: 313-317.

8. KUNTZ, J. E. and A. J. RIKER, 1949. Winter injury versus disease in Wisconsin poplar plantings. Phy topath. 39: 12. 
CRAIGHEAD, E. C. 1924. Studies on the spruce budworm (Cacocia fumiferana Clem.) Part II. General bionomics and possibilities of prevention and control. Can. Dept. Agr. Tech. Bull. 37 (n.s.).

GREENBANK, D. O. 1957. The role of climate and dispersal in the initiation of outbreaks of the spruce budworm in New Brunswick. II. The role of dispersal. Can. Jour. Zoology 35 : $385-403$.

HENSON, W. R. 1951. Mass flights of the spruce budworm. Canad. Ent. 83:240.

KENDEIGH, S. C. 1947. Bird population studies in the coniferous forest biome during a spruce budworm outbreak. Ontario Dept. Lands and Forests, Div. of Res., Biol. Bull. 1.

LACHANCE, P. E. 1954. A study of the pulp and paper industry of the Province of Quebec in relation to its present and future wood supplies. Pulp and Paper Mag. of Can. 55: 276-332.

McLINTOCK, T. F. 1955. How damage to balsam fir develops after a spruce budworm epidemic. Northeastern For. Experiment Station Paper 75: $18 \mathrm{pp}$

MORRIS, R. F. 1954. A sequential sampling technique for spruce budworm egg surveys. Call. Jour. Zoology 32: 302-313.

MORRIS, R. F., CHESHIRE, W. F., MILLER, C. A., and D. G. MOTT, 1958. The numerical response of avian and mammalian predators during a gradation of the spruce budworm. Ecology 39: 487-493.

WEBB, F. E. 1955. Biological assessment of aerial forest spraying against the spruce budwom in New Brunswick. I. Timing of operations 1952-54. For. Chron. 31: 342-352.

WEBB, F. E. 1958. Biological assessment of aerial spraying against spruce budworm in New Brunswick. II. A review of the period 1952-1956. Proc. 10th Int. Congr. Ent., 1956, 4: $525-531$.

WEBB, F. E., MACDONALD, D. R. and D. G. Cameron, 1959. Aerial spraying against spruce budworm in New Brunswick-1958. Bi-Mon. Prog. Rept. Div. For. Biol., Dept. Agr. Can., 15 (1): 1-2.

(Continued from Page 208)

9. MUNNS, E. N. and J. H. STOECKELER, 1946. How are the Great Plains shelterbelts? Jour. Forestry 44: 237-257.

10. NAGEL, C. M. 1949. Leaf rust resistance within certain species and hybrids of Populus. Phytopath. 39: 16.

11. RILEY, G. G. and A. J. SKOLKO, 1942. Resistance to disease in poplar breeding materials. Confidential Report.

12. SKINNER, F. L. 1956. Poplar breeding at Dropmore. Confidential Report.

13. STOUT, A. B. and E. J. SCHREINER, 1933. Results of a project in hybridizing poplars. Jour. Hered. 24: 217-229.

14. VAARTAJA, O. Personal correspondence. 1956-57. 